\title{
Saving on Clay: The Linear B practice of cutting tablets
}

\author{
Helena Tomas
}

University of Zagreb

\section{Introduction}

In this chapter I address the theme of writing as material practice through a case study on Aegean clay tablets and the procedure of cutting them into smaller tablets. Rather than setting the scene with a full overview of Aegean Bronze Age writing, a task that is ably accomplished in Helène Whittaker's contribution to this volume, I summarise the information most relevant to my topic. Helène informs us that Linear B was the oldest Greek script, and was preceded by another two major Aegean scripts, both mostly used in Minoan Crete and still undeciphered Cretan Hieroglyphic Script and Linear A. The signaries of these three Aegean scripts, as well as the types of material surfaces on which they were inscribed, are more or less related. All three are syllabic scripts and employed mostly for writing down economic and other administrative matters of related societies (Shelmerdine and Bennet 2008; Tomas 2010; Younger and Rehak 2008: 173-177). Although many types of clay sealings were used for recording this administrative business, the clay tablet is the most prominent document type in Linear A and Linear B, whereas in Cretan Hieroglyphic it is present only in small quantities.

While the clay tablet is chosen as a focus of this chapter, it is important to stress at the outset that despite all being 'clay tablets', the three groups of documents - Cretan Hieroglyphic, Linear A and Linear B - display significant differences, as I have pointed out elsewhere (Tomas 2011). These differences concern physical features of the tablets (so-called pinacological features) and methods of organising text on them (epigraphical features), as well as semantic contents of the inscribed text. From all these a single pinacological feature has been selected for consideration here - the cut edges of clay tablets (with a special emphasis on Linear B tablets). The reason for such a narrow selection is motivated by the fact that some

\section{How to cite this book chapter:}

Tomas, H. 2013. Saving on Clay: The Linear B practice of cutting tablets. In: Piquette, K. E. and Whitehouse, R. D. (eds.) Writing as Material Practice: Substance, surface and medium. Pp. 175-191. London: Ubiquity Press. DOI: http://dx.doi.org/10.5334/bai.i 
aspects of the practice of cutting clay tablets are among the most enigmatic of all pinacological features of Aegean clay tablets, yet they seem to reveal a very important administrative procedure, as will be elaborated below. Also this choice of topic fits particularly well the subject of this volume, since cutting of clay is a pre-eminently material practice, related to the specific material employed.

\section{A Brief Outline of Aegean Clay Tablets}

\section{Chronology and Distribution}

At present it remains unclear which of the two Minoan scripts is earlier. The answer to this question lies in the interpretation of the inscriptions from prepalatial seals of the so-called Archanes Script (Godart and Tzedakis 1992: 108, 121-122; Grumach and Sakellarakis 1966; see also Flouda, this volume; Whittaker, this volume): some interpret them as Cretan Hieroglyphic, some as Linear A (Godart 1999; Olivier and Godart 1996; Sakellarakis and Sapouna-Sakellaraki 1997: 326-330). For the present study, however, such a chronological intricacy has no crucial relevance, since the earliest preserved clay tablets postdate these Archanes seals. (I do not intend to get involved in a detailed discussion of the absolute chronology of the Aegean Bronze Age here. It suffices to say that Middle Minoan (MM) covers a period of c.2100 / 2000-1700 / 1600 BC and Late Minoan I (LM I) a period of $c .1700$ / 1600-1450 BC; for a detailed discussion, see Warren and Hankey 1989; see also Whittaker, this volume.)

I have already mentioned that Cretan Hieroglyphic tablets are rare: two have been discovered in the Hieroglyphic Deposit of the palace at Knossos, two in the palace of Malia, and one in the palace of Phaistos (Olivier and Godart 1996: 122-123, 172-175, 182-183). Whereas the Phaistos example is of an uncertain date, and the precise date of the Knossian Hieroglyphic Deposit is still a subject of debate (for the latter see the overview of different opinions in Schoep 2001: 147-148), the two tablets from Malia are securely dated to the MM III period (Chapouthier 1930).

A total of some 350 tablets has been discovered amongst Linear A documents, although many in a fragmentary state (Godart and Olivier 1976-1985). The earliest Linear A tablets are an MM IIA example from Knossos (del Freo 2007: 204-205; Schoep [2007] suggests that this may in fact be a Cretan Hieroglyphic tablet) and some 20 tablets from the MM IIB layers of the palace at Phaistos (Pugliese Carratelli 1958). Only a small number of Linear A tablets are of the MM III date while the majority are from the final phase of the administrative use of Linear $\mathrm{A}$, that is, the end of the LM IB period ( $c .1450 \mathrm{BC}$ ), with the largest number, 147 tablets, coming from Haghia Triada (Ayia Triada) (Halbherr et al. 1977).

At least 5000 tablets with Linear B are known. The earliest are c.650 tablets from the Room of the Chariot Tablets at Knossos (hereafter RCT), dated to LM II or early LM IIIA1 (Driessen 1990: 117). The remainder of the approximately 2800 Knossian tablets are probably of LM IIIA2 date (the most recent overview of disputes concerning the date of the final destruction of Knossos and therefore of the majority of its Linear B tablets, is given in Driessen 2008: 70-72; the corpus of Knossian tablets is published by Chadwick et al. 1986-1998). Other Linear B tablets come from Chania on Crete and major Mycenaean centres on the Greek Mainland. Apart from a few odd examples from the LH IIIA period (Palaima 1983; Shelton 2002-2003), these are all of the LH IIIB date. The Pylos archive with approximately 1100 tablets is the largest in this group (Blegen and Rawson 1966: 92-101). It is followed by nearly 400 tablets from Thebes (Aravantinos et al. 2002; 2008), while there are smaller numbers of tablets from Mycenae, Tiryns and Chania (AndreadakiVlasaki and Hallager 2007; Godart 1988; Hallager and Vlasaki 1997; Melena and Olivier 1991; Sacconi 1974). 


\section{Shape}

There are two principal shapes of Aegean clay tablets: the elongated (also called palm-leaf shaped tablets) and the page-shaped. Linear B makes use of both shapes (the former were used for simple entries, the latter for summarising records, cf. Driessen 1999: 207-208), whereas only pageshaped tablets were employed during the latest stages of Linear A. We do find several elongated tablets inscribed in Linear A, but they are dated to MM II or MM III; no elongated tablets with Linear A have been found amongst the latest surviving, LM IB documents. It should be noted that some LM IB Linear A tablets are far too fragmentary to make a definite decision about their shape, but, since not a single complete elongated tablet has been preserved in any LM IB deposit, we can assume that those tablets that are now fragmentary were also page-shaped when complete. As for Cretan Hieroglyphic tablets, the five preserved examples are all elongated, but thicker than most Linear A and Linear B elongated tablets.

\section{Size}

Linear A page-shaped tablets are generally smaller than Linear B ones, as is the average amount of information on them (on complete Linear A tablets the average number of signs per tablet is only 30). The overall proportion of the size of tablets and the 'crowdedness' of signs inscribed on them shows that Linear B page-shaped tablets hold a larger amount of information on the available space. As proposed elsewhere (Tomas 2011) there may be several reasons for this: the different nature of the two languages being recorded (Linear A sign-groups, i.e. words, are generally shorter than those of Linear B, see Duhoux 1978: 68), different methods of recording information (for example, Linear A may have used abbreviations more frequently), or different administrative practices (for example, Linear B page-shaped tablets may have been intended to contain more information than Linear A page-shaped tablets; perhaps in Linear A more extensive information was recorded on some other material, possibly perishable, cf. Driessen and Schoep 1999: 392; Olivier 1987: 230).

The small number of Cretan Hieroglyphic and Linear A elongated tablets precludes any sensible comparison to their numerous counterparts in Linear B, especially since the nature of elongated Linear B tablets changed drastically over time. Thus, elongated tablets tend to be smaller and with little text in the RCT, larger in the later Knossian deposits, and much larger and with more abundant text at Pylos. Driessen (1988: 132) notes that very small elongated tablets are frequent in the RCT and completely absent elsewhere: their dimensions are less than $0.6 \mathrm{~cm}$ thick, less than $0.2 \mathrm{~cm}$ high and less than $0.4 \mathrm{~cm}$ long. Their small size suggests that they were meant to be documents that could easily be carried around by individuals. Since it is precisely this type of tablet that in Linear B is most frequently the outcome of cutting (i.e. dividing of a larger tablet into smaller ones) they will be addressed below in more detail.

\section{The Practice of Cutting Aegean Clay Tablets}

The practice of cutting tablets is evident in both Linear A and Linear B administrative systems. The tablets were cut while still moist, probably with a knife, or other sharp tool. The few surviving Cretan Hieroglyphic tablets do not show traces of cutting, but this does not necessarily mean that this practice was unknown to the system.

The reasons for this practice seem to be clearer in Linear B than in Linear A. In Linear B, tablets were most probably cut after having been inscribed, when the residue of clay with no text was removed, possibly to be reused to form other tablets or to economise on space needed for their 


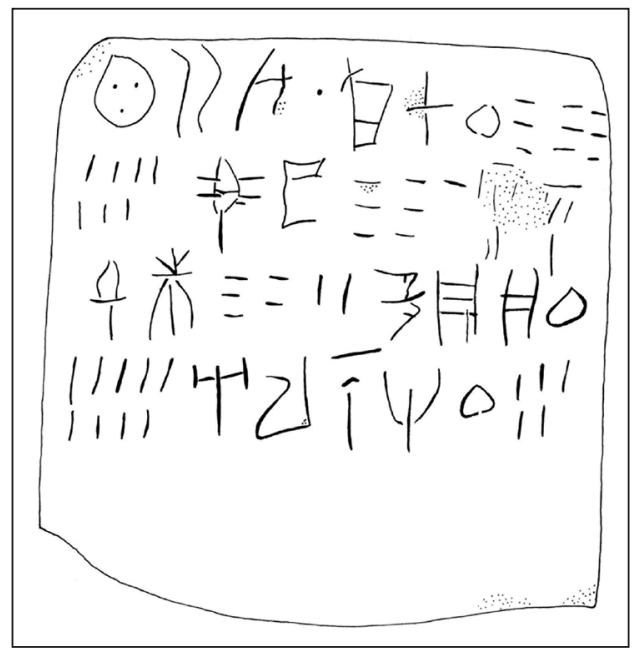

Figure 1: Linear A tablet HT 1, $6.60 \times 7.00 \mathrm{~cm}$ (Godart and Olivier 1976: 2).

transport and storage (see below). It is mostly elongated tablets that were cut (on their left or right side, or even both sides), whereas page-shaped tablets were cut only occasionally (usually at the bottom, exceptionally at the top). This habit of cutting tablets is especially apparent in the RCT, where about $20 \%$ of tablets were cut (whereas only $5 \%$ of the rest of the Knossian tablets were cut, cf. Driessen 1988: 134), and most of those are of an elongated shape. In addition to removing non-inscribed clay, another explanation has been proposed for the cutting of the RCT elongated tablets: the practice of dividing a set of information into separate records. By rejoining these small elongated tablets one can easily see that they initially belonged to one larger tablet. The name introduced to describe this kind of document is a 'simili-join': larger tablets were probably divided into these smaller units for the purpose of rearranging the information (Driessen 1987), as is further elaborated below. Simili-joins are a feature almost unique to the RCT.

In comparison to Linear B, the practice of cutting tablets in Linear A is less well-understood. In Haghia Triada, the site with the largest number of Linear A tablets (147), only 10 tablets are cut, most of them at the bottom, some on their right or left sides (see also Schoep 1998-1999: 279). We cannot claim here that this was done, as in Linear B, after the text was inscribed and in order to remove a blank and therefore superfluous part of the tablet. In fact the scribes of the Haghia Triada tablets seem not to have been so preoccupied with saving space on tablets or neatness of filing. In most cases, when the tablets were cut, this was not done immediately below the end of the text, but further down or on the side, thus leaving plenty of unused space (e.g. HT 1, HT 2, HT 21, HT 92, HT 133, HT 154B, Figure 1). This suggests that the tablets at Haghia Triada were cut before they were inscribed and that the estimation of the space needed for the text was often incorrect, since many cut tablets are still too large for the inscribed text. By contrast, the tablet HT 10a was cut and then was too small for the required text, so the numbers at the end of the bottom line were crammed into the corner (Figure 2). (There is another possible explanation for the lack of space on this tablet: the tablet is a palimpsest, which means that it was probably cut to fit an erased text that was shorter than that which is preserved; cf. Piquette, this volume.)

Such a lack of coordination between the size of Haghia Triada tablets and the length of their inscriptions tells us something about the process of producing tablets. It is obvious that a tablet was conceived separately from the text, and at the time of its production the scribe did not yet have a clear idea of the amount of the text to be written thereon. Such a disparity furthermore suggests that the scribes of Haghia Triada did not produce their own tablets, but had assistants for 


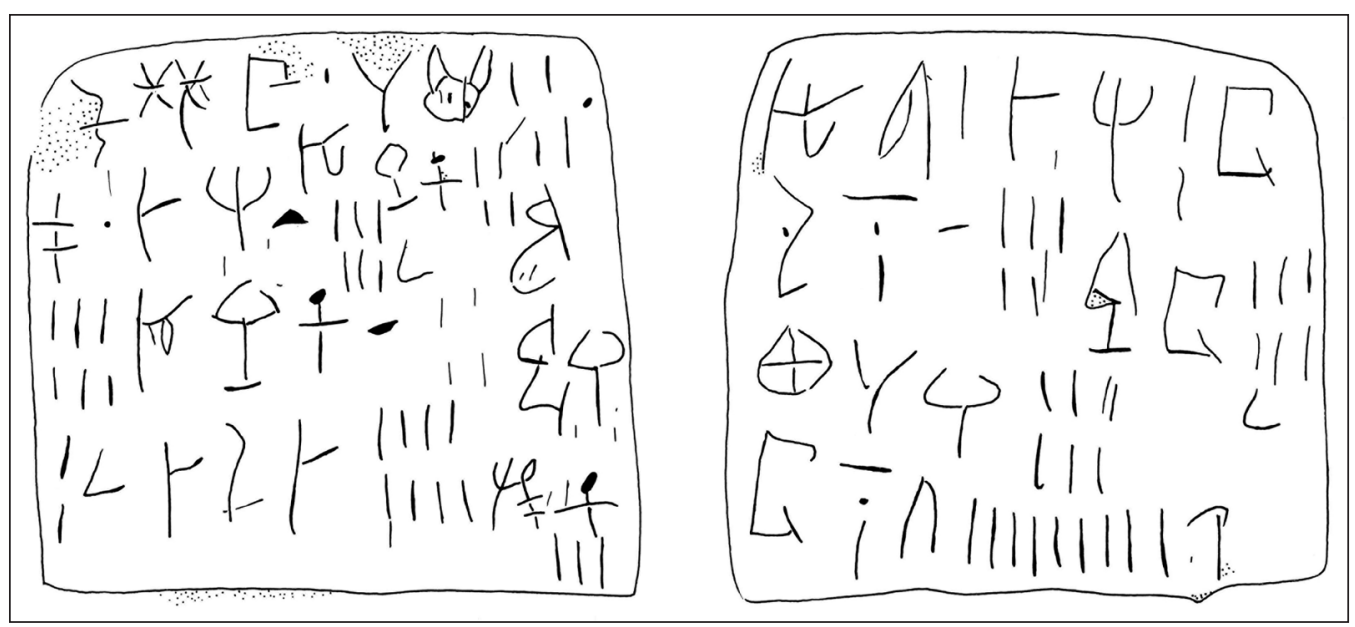

Figure 2: Linear A tablet HT 10, recto left (HT 10a) and verso right (HT 10b), $6.10 \times 5.70 \mathrm{~cm}$ (Godart and Olivier 1976: 20).

that task, so called 'flatteners'. The opposite may be argued for the Linear A tablets from Chania. If we compare these to tablets from Haghia Triada, we notice that the former display a much better correlation between the size of a tablet and the length of its inscription. When Chania tablets were cut, this was in most cases done immediately beneath the last line (for example, $\mathrm{KH} \mathrm{6,} \mathrm{KH} \mathrm{8,} \mathrm{KH}$ 9, $\mathrm{KH} \mathrm{10,} \mathrm{KH} \mathrm{21,} \mathrm{KH} \mathrm{58,} \mathrm{etc.).} \mathrm{This} \mathrm{means} \mathrm{that} \mathrm{the} \mathrm{collaboration} \mathrm{between} \mathrm{the} \mathrm{scribe} \mathrm{and} \mathrm{the} \mathrm{flat-}$ tener was much closer in Chania than in Haghia Triada - or even that they were the same person (see also Schoep 2002: 76).

Whether a Linear A scribe and a flattener were the same person is an issue that requires a more thorough investigation, perhaps also a study of palm- and finger-prints which has helped to resolve similar questions in the case of Linear B tablets. Thus, Sjöquist and Åström's (1991) study of palm- and finger-prints in Knossos has shown that the tablets were usually made by assistants, only occasionally by the scribes themselves. The flatteners were sometimes children, perhaps apprentices, and sometimes adults whose hands saw hard work (visible from their rough and extended pores; Sjöquist and Åström 1991: 7, 20, 29-30). In contrast, for the case of Pylos, Palaima argues that scribes made their own tablets. His conclusion is not based on palm- and finger-prints, but on shapes of tablets that are characteristic of certain scribes (Palaima 1985: 102; 1988: 27; for a discussion of the correspondence between scribes and flatteners in the RCT, see Driessen 2000: 43-44, who concludes that they were never the same person; see also Firth 2012).

Until questions like this are answered for the Linear A tablets as well, we may provisionally conclude that Linear A scribes / flatteners had little foreknowledge of the amount of text that had to be fitted on a tablet. As for the cutting of tablets, it has been shown that this practice was less common in Linear A, and was also - Chania tablets excepted - inefficiently practised. If the purpose of this practice was to accommodate shorter texts, as in Linear B, why are most cut tablets still too large for the inscribed texts?

\section{A More Detailed Discussion of Cutting Tablets in Linear B}

In the above section two principal explanations are given for the practice of cutting Linear B tablets: saving on clay and rearranging the information. Let us now explore these two possibilities in more detail. 


\section{Saving on Clay}

The easiest explanation for cutting Linear B tablets is saving on clay, since its surplus could be reused for producing further tablets. However, since clay is not a particularly scarce substance in Greece, saving was probably not the main motivation behind the practice of cutting tablets. A more likely aim appears to be a reduction of the size of tablets, and consequently of their weight, in order to economise on the space needed for their storage (for the maximum of one year, as numerous studies have shown). How were Linear B tablets stored?

In most cases Linear B tablets were found in such a state that it is impossible to say much about their initial storage. All over Knossos they were found in a secondary position, having fallen from the upper floor(s) during the destruction of the palace. The most we can say therefore is that Linear B archives in Knossos were stored above the ground floor: the upper rooms, with a good source of light, would have been an adequate setting for writing purposes (Begg 1987), but exactly what these archives looked like we do not know. The relatively small quantities of tablets from Mycenae, Tiryns and Chania make it difficult to discuss their archives. As for the fairly numerous Thebes tablets, their archaeological context is very much disturbed (Aravantinos et al. 2002: 8-15), which mostly precludes discussions about the organisation of the archive(s).

The only Linear B archive where a more precise method of storing tablets is known is the Archives Complex of Pylos, thanks to its placement on the ground floor. Here more than 1000 tablets were stored, probably on wooden shelves (Pluta 1996-1997: 240-241; for the meaning of the word 'archives' applied to Linear B administration see Olivier 1984: 15-18; Pluta 1996-1997: 240-241). The small size of the two archive-rooms and the construction of the shelves, possibly not fit for a heavy load, may have required strict removal of superfluous clay on tablets. However, until the corpus of Pylian tablets is published (with facsimile drawings and photographs), it is difficult to say if the storage method was in any way related to the practice of cutting the tablets; at this moment we cannot say what percentage of Pylian tablets was cut and what was the relationship between the amount of inscribed texts and cutting of the tablets. ${ }^{1}$

The transport of tablets within the palace may have also required removal of unused clay. It has been suggested that tablets were transported in wicker baskets on top of which clay labels were pressed. These labels had no string that would attach them to the baskets, but were simply pressed against them while the clay was still moist, so traces of wickerwork are visible on their backs. They had no seal-impression, but were incised (Wb series at Knossos: 35 examples, Wa series at Pylos: 19 examples). These labels labelled various sets of tablets as they were delivered to the archive, or as they were stored and filed (Blegen and Rawson 1966: 97; Chadwick 1958; Palaima 1988: 179; Palaima 1996: 380, n. 3; according to Palaima and Wright 1985: 260-261, labels were confined to transport only, and their small number in the Archives Complex suggests that they were probably not kept there for long after the baskets arrived; otherwise many more would have been found).

\section{Rearranging the Information}

This section takes us back to the RCT documents and already mentioned simili-joins. The practice of cutting the tablets is especially apparent in the RCT; here 124 tablets (nearly 20\%) were cut, on their left or right side or even both sides. This group of documents consists of approximately 645 tablets (for a thorough study of these tablets see Driessen 2000). Only some 20 are page-shaped, and the rest are elongated. Nearly all tablets from the RCT that have been cut are elongated. Only a single page-shaped tablet from this deposit, $\mathrm{KN}$ Ap 5077, has traces of cutting (on the bottom). This tablet is a palimpsest. The text runs along its upper half, while the bottom half is not inscribed. Since the tablet is too large for the text that is preserved, it seems that it was cut after the tablet was inscribed for the first time (a similar explanation may, for example, be valid for cut KN Gm 840, not an RCT tablet, Figure 3). 


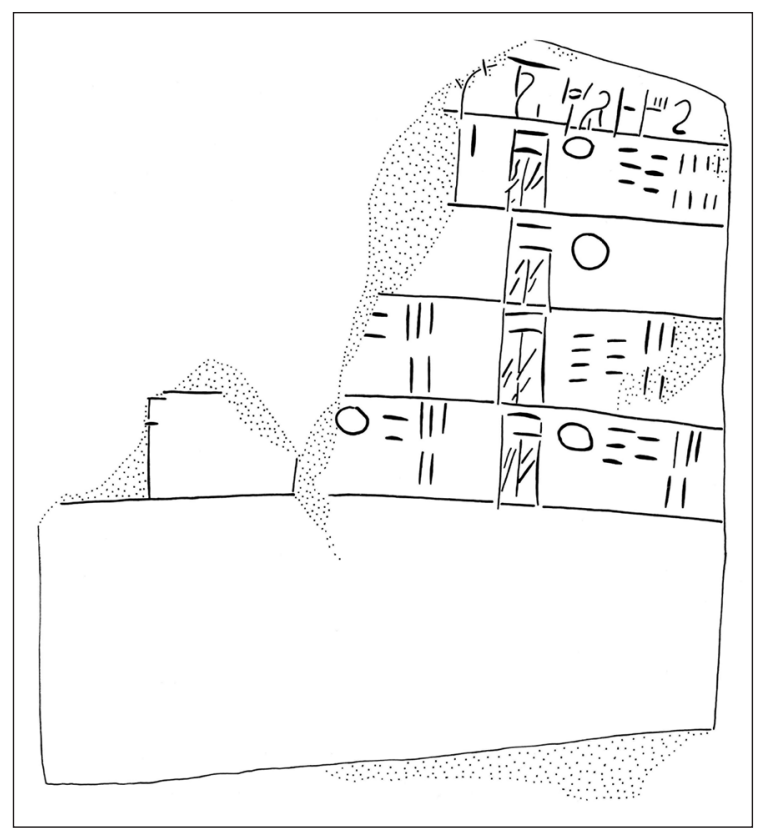

Figure 3: Linear B tablet KN Gm 840, $10.70 \times 11.10 \mathrm{~cm}$ (Chadwick et al. 1986: 333).

Elongated RCT tablets are typically cut on their right or left sides, immediately before the first sign or immediately after the last one, which suggests aiming to save on clay wherever possible. The RCT tablets generally give an impression of economy: the entire surface of the tablet is usually inscribed, without leaving any unused space, and when a tablet proved larger than needed, the unneeded parts seem to have been excised. The practice of cutting is especially frequent in the Vc and Sc series of the RCT tablets (lists of people and armour respectively), but also amongst scribes 115 and 141, who also worked in the south part of the West Wing of the Knossian palace (Driessen 1988: 135).

As mentioned above, another explanation has been proposed for the cutting of these RCT elongated tablets: the practice of dividing a set of information into separate records. This interpretation is suggested by some features of the $\mathrm{Vc}(1)$ set, in which the tablets consist of a personal name followed by the number one and a cut immediately after that (Chadwick 1968: 18). Driessen managed to join together a number of tablets of the $\mathrm{Vc}(1)$ series, and some of the tablets of the $\mathrm{Xd}$ series, proving that these small elongated tablets initially belonged to one larger tablet, and named them, as already said, simili-joins. Simili-joins are indicated by a plus sign inscribed in a circle in text editions. ${ }^{2}$

Apart from the actual cutting, another feature may be an indication of the practice of similijoins. A certain number of elongated tablets from the RCT, of the Vc and Vd series, have vertical lines incised across them. ${ }^{3}$ These lines are too long to be either word-dividers or numerals; they run practically from the top of a tablet to the bottom. It seems that their function was to divide certain sections of a tablet. The best example is Vd 7545+137 (Figure 4) where we can see three, possibly even four, such lines dividing the contents of the tablet into at least four sections (because the tablet is partly damaged, possible additional vertical lines are no longer visible). Perhaps vertical lines on this and other RCT tablets were incised to indicate where to cut them (Driessen 2000: 55). Evans (1935: 695) already entertained this possibility, suggesting that the purpose of these lines was to divide the tablet into six units but if so, the question is: why did they remain undivided? Although a significant number of such tablets were left undivided, I believe that it is correct to interpret incised vertical lines as indicators for cutting (note, however, that Duhoux [1999: 


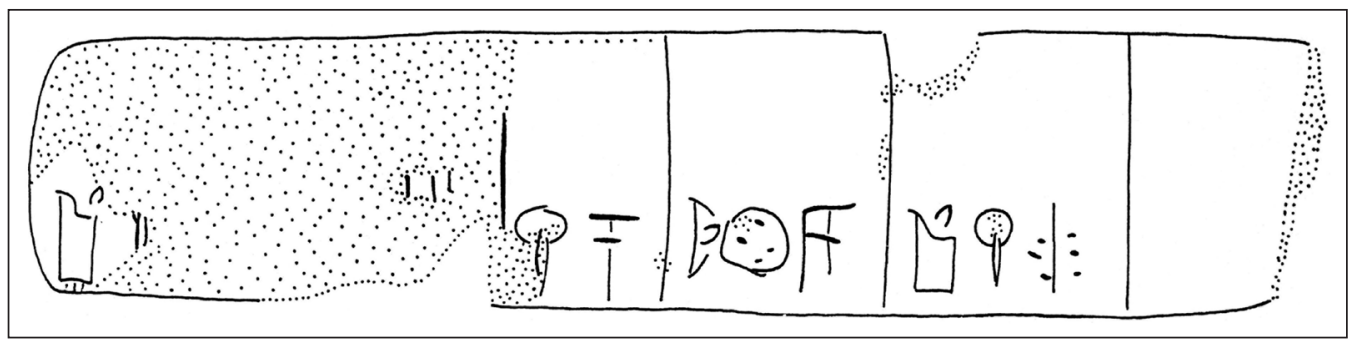

Figure 4: Linear B tablet KN Vd 7545+137, $15.6 \times 3.35 \mathrm{~cm}$ (Chadwick et al. 1997: 252).

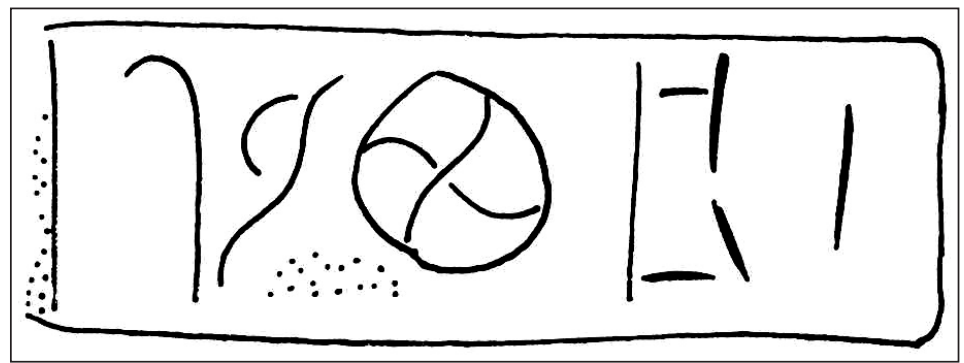

Figure 5: Linear B tablet KN Vc 64, $3.8 \times 0.75 \mathrm{~cm}$ (Chadwick et al. 1986: 37).

$228, \mathrm{n} .10$ ] is not convinced about such an interpretation). Here is one example that supports this interpretation. On Vc 64 (Figure 5), a vertical line runs along the left edge of the tablet. We know that this tablet was cut at both ends, and has been identified as a simili-join. At least here we have evidence that the tablet was cut where indicated by an incised line.

As for the purpose of simili-joins, Driessen suggests that larger tablets were divided into smaller units for the purpose of rearranging the information: “...the men were booked for one reason, perhaps something they all had in common. This relationship was broken to create another one" (Driessen 1987: 161). I agree with Driessen on this matter, and here is a possible scenario of the purpose of such rearranging. The Vc series is composed of tablets with a personal name, often followed by the number one. ${ }^{4}$ They may be individual records of people. Driessen has argued (1992: 202-203) that the Sc series represents the allocation of military equipment, the interpretation which is accepted by Oliver (1994: 54), whereas Vc tablets list individuals who were already equipped. As we have seen, some of these Vc tablets were initially parts of longer records that were divided into units - simili-joins. The initial record may have simply listed the names of people. By dividing this list into individual records, the information could have been rearranged as required, for example, according to the status of the people recorded, or according to their type of work (paid work or un-paid, slave work), or according to their particular duties, such as potters, textile workers, leather workers, etc. (a colleague once humorously reacted to this idea, describing my scenario as the earliest Excel system in Europe). Records of this type were probably written with the anticipation of a need to rearrange the data, meaning that the simili-joins may have been planned in advance. Hence the practice of marking tablets with vertical lines for cutting. These lines must have been incised when the tablet was still moist, i.e. either while inscribing the text, or not long afterwards.

Simili-joins are a feature almost unique to the RCT. We rarely find it anywhere else in Linear B and never in Linear A. The only other Linear B example, as detected by Olivier, is simili-joins B $7035 \oplus \mathrm{B} 808$. The latter was found in the Long Corridor at Knossos, but the findspot of B 7035 is unknown (Driessen 1987: 161). Simili-joins from the RCT may be another reason for believing that this deposit is chronologically different from the rest of the Knossian documents. The 
practice of simili-joins may have been an early and experimental Linear B feature that ceased after the RCT period. A single later example $(\mathrm{KN} \mathrm{B} 808 \oplus \mathrm{B} 7035)$ could be regarded as a short-lived legacy from the preceding RCT practice, which afterwards disappeared from the rest of the Linear $\mathrm{B}$ records, both on Crete and the Mainland. It must be noted, though, that lines possibly incised for the purpose of dividing a tablet have also been noticed at Mycenae. In this case, the lines are horizontal (e.g. at the bottom of the tablets MY Oe 117 and MY Oe 120, but are no longer easily visible since the tablets were snapped in two at this spot). Emmett Bennett noticed that these lines were incised more deeply than the ruling lines on these two tablets. He suggested that the purpose of these deeper incisions was precisely to facilitate the snapping of a tablet into two parts: "This would be equivalent to writing a line at the top of a sheet of paper and then folding it over and tearing off the top line" (Bennett 1958: 13).

Although the practice of incising lines for the purpose of dividing tablets is not recorded outside Linear B, there is a feature in Cretan Hieroglyphic that at least visually resembles it. Several Cretan Hieroglyphic tablets and bars are incised with vertical lines. ${ }^{5}$ We saw that in the RCT these lines probably indicated where an elongated tablet was to be cut into separate, smaller tablets. The arrangement of vertical lines on Hieroglyphic documents, however, casts doubt on the idea that they had a similar purpose.

Most Cretan Hieroglyphic documents with vertical lines are inscribed on more than one side: four-sided bars are inscribed on all four sides, two-sided bars and one tablet are inscribed on both sides. RCT elongated tablets with vertical lines, on the other hand, are never inscribed on their versos. Moreover, vertical lines on Cretan Hieroglyphic documents rarely correspond in their position, so that if one were to cut the document following the vertical line on one side, the text would be severed on the other sides.

Some Cretan Hieroglyphic documents have two lines of text inscribed on one side and divided by a ruling line. The vertical lines on them are either not placed underneath each other, or appear in only one line and not in the other (for example, \#063.a, \#113.b, \#120.a). It seems that in these cases the vertical lines are used to divide the information, i.e. separate entries into sections, rather than to divide the actual tablet. ${ }^{6}$ Since in a few cases these vertical lines separate a sign-group from a number, they are used differently from the word-dividers known from Linear A and Linear B, which may separate sign-groups, logograms or transaction signs, but do not separate these categories of information from the following or preceding numbers. In Linear A it was usually the case that an entry ended with a number, and the next sign-group was therefore part of a new entry. This practice made it unnecessary to place a word divider between a number and the following signgroup in order to stress that they referred to separate entries, hence the small number of worddividers in Linear A (Tomas 2003: chapter III, \$5.7). However, it seems that Cretan Hieroglyphic needed to mark the separation of entries, and that vertical lines were employed for that purpose.

This brief study of the vertical lines on Hieroglyphic documents does not support a connection with the vertical lines on the RCT documents: the former appear to be used to separate entries, and the latter to guide the cutting of the tablet. That said, Olivier has noticed (1994-1995) that bars \#057 and \#058 (Figures 6-7) match nicely when placed against each other - they must have made up a single bar that was cut into two separate documents. Olivier consequently refers to them as 'simili-raccord', following Driessen's term (1987) 'simili-joins'. Three sides of bar \#057 have vertical lines. Although there is no line on the fourth side, Olivier argues that a line was initially there, but is no longer visible after the bar had been cut. Both parts have holes for suspension. Oliver claims that the two bars were inscribed by two different hands (1994-1995: 262), which was never the case with simili-joins in the RCT. All RCT simili-joins were inscribed by only two hands: $124 \mathrm{r}$ and 124s. Of these two, however, it was always the same hand that inscribed the matching simili-joins (Driessen 1987: 156-157, 162).

Let us now return to the topic of rearranging data on the RCT elongated tablets and examine another argument in favour of such an interpretation. Some of the RCT elongated tablets have a 


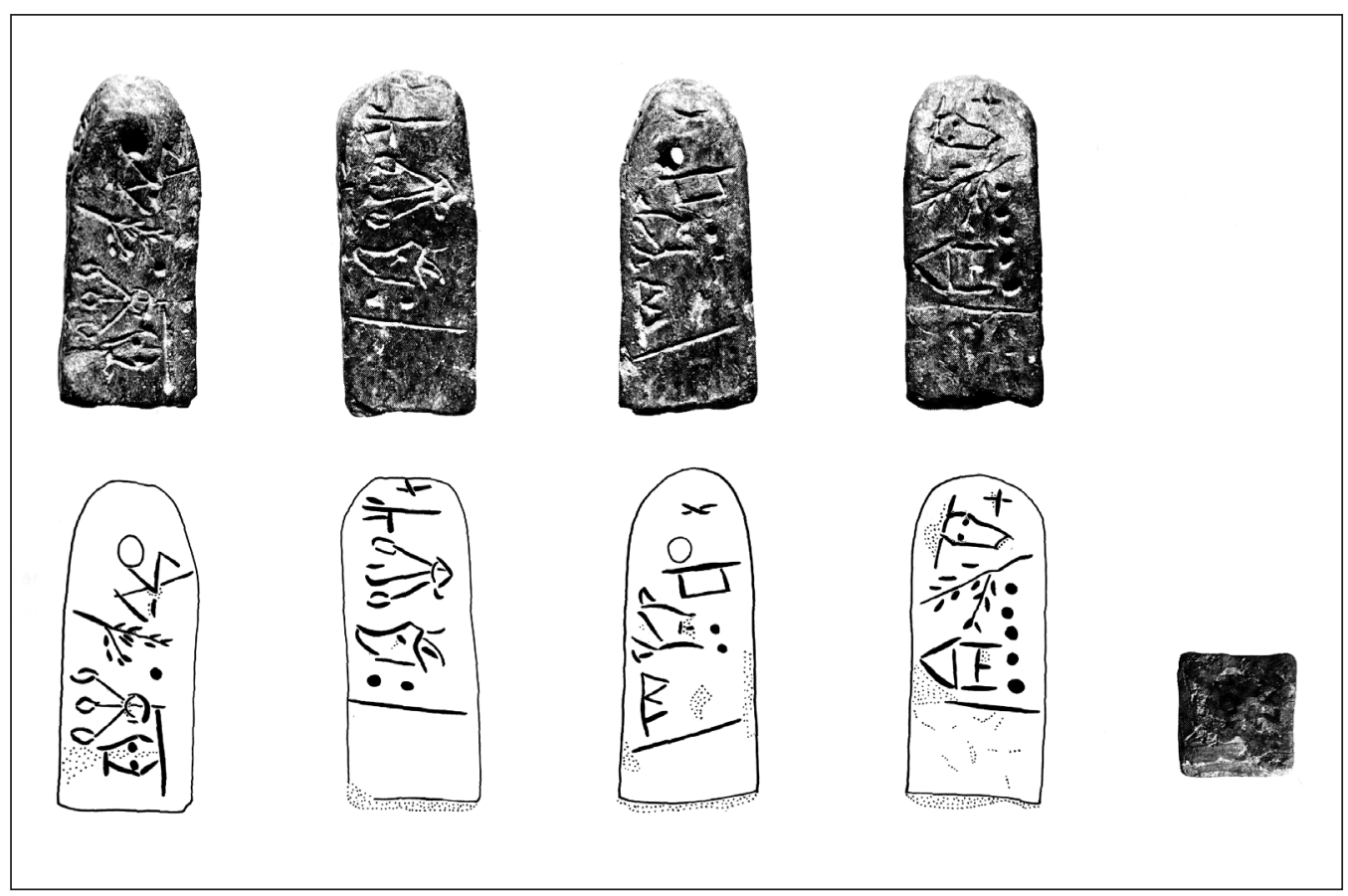

Figure 6: Cretan Hieroglyphic bar KN Hh (04) 02 / \#057, $1.8 \times 4.6 \times 1.7 \mathrm{~cm}$, circles on the first and third drawing are the holes for suspension (Olivier and Godart 1996: 110).

single sign inscribed on their verso (e.g. Xd 94+187, Vc173, Vc 177, Sc 7457, Xd 7813+7953, see Figure 8), or a single word, most commonly a complete or incomplete form of the ethnic a-mi-nisi-jo (Sc 217, Sc 237, Sc 252, Sc 7476, Sc 7772, Sc 7782+8568, Sc 8471, see Figure 9). Since some of these tablets show traces of cutting, it is possible that the purpose of single signs / words on the verso was reclassification according to, say, the origin of the people registered: from $a$-mi-ni-so the well-known site of Amnissos near Knossos (see Aura-Jorro 1985: 56). These tablets perhaps needed to be marked as different, since the other RCT elongated tablets seem to have dealt with only local business. Here follows the justification for the last statement.

Toponyms in the RCT records more commonly occur on page-shaped tablets. Out of 24 pageshaped tablets, 10 contain toponyms (42\%). Out of 585 elongated tablets, only 23 contain toponyms (4\%) (note that the shape of 36 RCT tablets cannot be determined due to their fragmentary state). Put in the context of the total of different words, $21 \%$ of the vocabulary from page-shaped tablets are toponyms, compared to only $6 \%$ in the case of elongated tablets (all counts are from Tomas 2003: chapters 2-3). One the one hand, this may indicate a difference in the function of the two types of documents in the RCT, namely that page-shaped tablets more often recorded transactions that involved the mention of toponyms, i.e. references to non-local business. Due to their low number of toponyms, on the other hand, it may be argued that the RCT elongated tablets were mainly involved in local transactions (cf. Bennet 1988:21-22, n. 8, who pointed out that the majority of Linear B tablets do not contain place-names, in which case we assume that they refer to the storage of goods or activities conducted at the centre). If that is so, those elongated tablets with $a-m i$-ni-si-jo on their verso can be seen as an exception to this practice, and perhaps relate to individuals from $a$-mi-ni-so. This may be the reason why these tablets were differently marked, to distinguish them from the other elongated tablets that typically referred to transactions with individuals from Knossos. Driessen similarly uses two RCT examples of the ethnic $i$-ja-wo-ne (Xd 


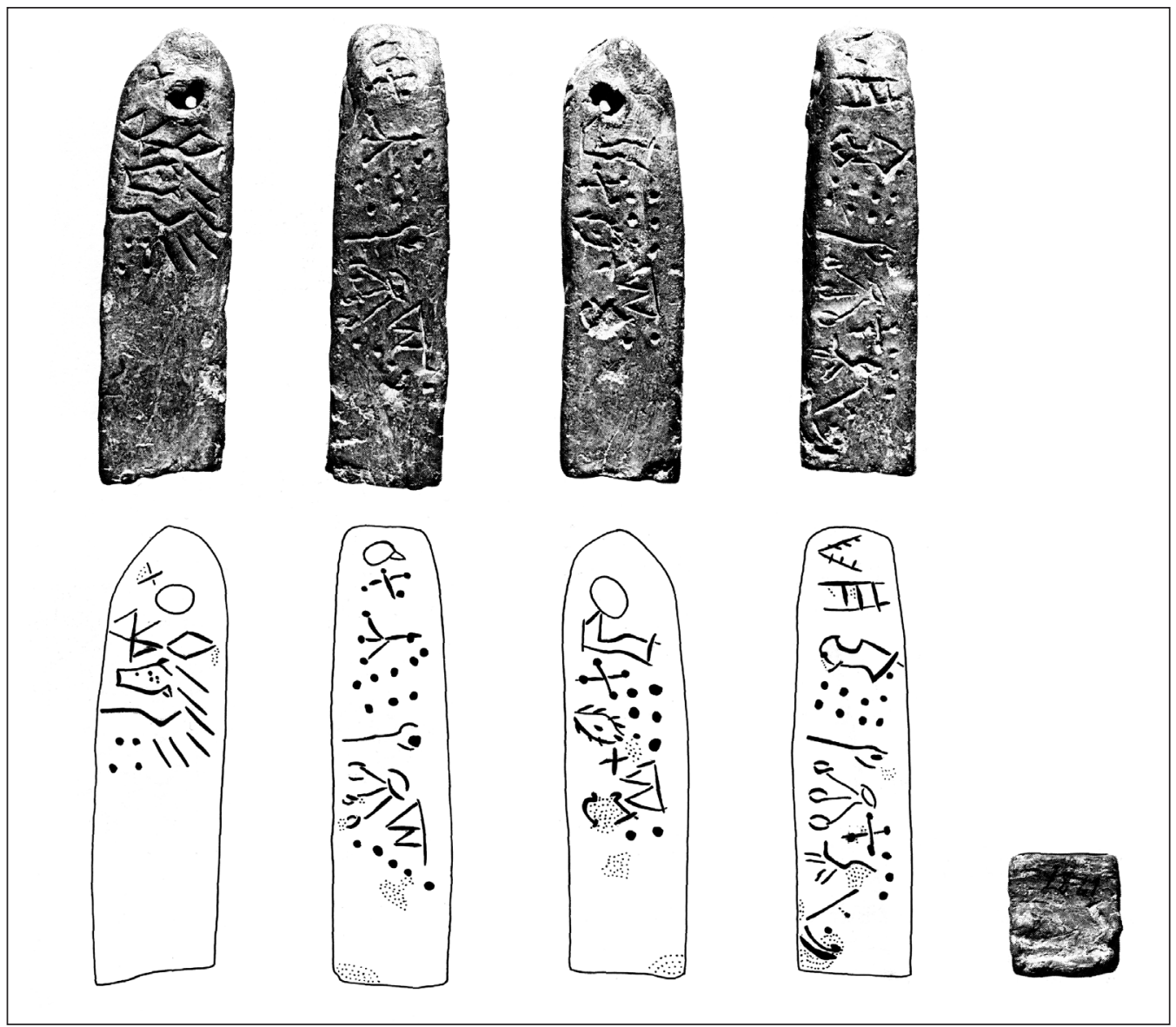

Figure 7: Cretan Hieroglyphic bar KN Hh (04) 03 / \#058, $1.8 \times 6.8 \mathrm{~cm}$, circles on the first and third drawing are the holes for suspension (Olivier and Godart 1996: 111).

146.4, B 164.4) to argue that this group of people (Ionians) "must have been considered different from the groups the palace usually dealt with to deserve a specific ethnicon" (Driessen 1998-1999: $85)$.

If we accept that examples of $a$-mi-ni-si-jo on the verso mark out mentioned tablets as different from the rest, meaning that they may have dealt with non-local individuals, we can assume that these examples of $a$-mi-ni-si-jo were subsequently incised as classifying marks, according to which the elongated tablets may have been rearranged. Opisthographic tablets (i.e. those inscribed on both sides) are rare amongst the RCT elongated tablets - only 44 are opisthographic, $8 \%$, (counts in Tomas 2003: chapter 3) - so inscribing a-mi-ni-si-jo on the verso was an exceptional epigraphic feature used to mark exceptional matters, that is, non-local transactions in the majority of tablets dealing with local ones.

It must be mentioned that $a-m i-n i-s i$-jo is not the only ethnic mentioned on the RCT tablets. Altogether 10 ethnics have been recorded in the RCT: two on page-shaped tablets, and eight on elongated tablets (counts in Tomas 2003: chapter 2). Most occur elsewhere in Knossos, but $a-p u_{2}-$ $k a$ occurs only at Pylos apart from the RCT at Knossos. I am aware of the possibility that an ethnic can also refer to a place, like a toponym. In the RCT, however, it is also possible that ethnics denote people, i.e. an ethnic used instead of a personal name. This was already argued by Killen (1981: 


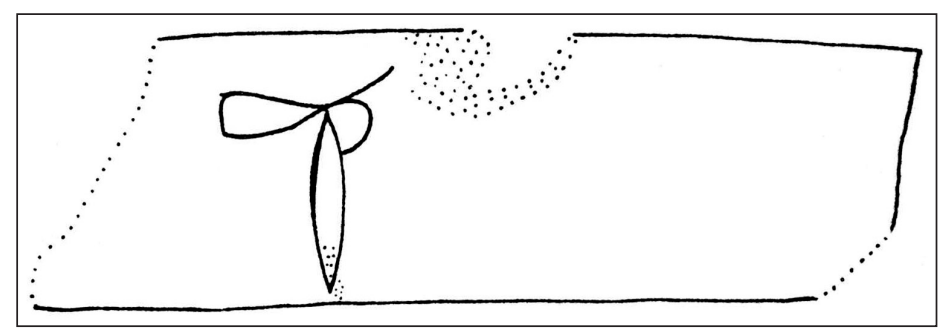

Figure 8: Linear B tablet KN Xd 7813+7953 verso, $5.9 \times 1.85 \mathrm{~cm}$ (Chadwick et al. 1997: 299).

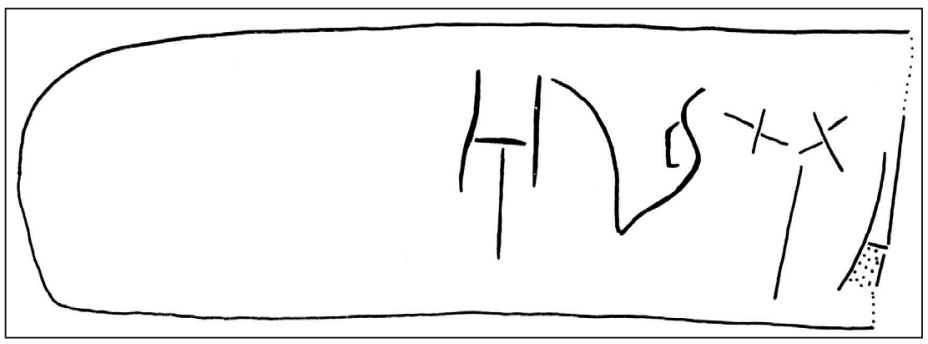

Figure 9: Linear B tablet KN Sc 237 verso, $7.3 \times 2.35 \mathrm{~cm}$ (Chadwick et al. 1986: 103).

80): “...the use of ethnics as personal names is a widespread phenomenon on the tablets". In that sense it is significant that ethnics occur more frequently on elongated tablets since a great majority of them records personal names. They are here listed in the same way as other personal names, so they do not stand out as denoting different business. A-mi-ni-si-jo is the only ethnic marked on the verso of tablets.

\section{Conclusion}

It has been shown that the practice of cutting clay tablets, as far as present evidence tells us, was known to two of the total of three Aegean administrative systems. Cretan Hieroglyphic tablets, preserved in small numbers, do not show traces of cutting. Cretan Hieroglyphic bars, on the other hand, do have a single case of cutting. Inscribed vertical lines on such bars resemble similar lines which marked where the Linear B (RCT) elongated tablets should be cut, but it was concluded that the lines on Cretan Hieroglyphic documents did not have the same function.

Reasons behind Linear A cutting, especially in Haghia Triada, remain unclear, since cut tablets are too spacious for the inscribed text, so getting rid of superfluous parts of tablets is not a valid explanation.

In Linear B, at least in Knossos, cutting was practised on both types of tablets, the difference being that page-shaped tablets are less frequently cut than elongated tablets. In both cases, two alternative procedures of cutting are possible: 1) that a scribe had no clear preconception of the amount of the text for the particular tablet, so the tablet was cut after having been inscribed in order to remove the residue of clay with no text; 2) that even before writing, a scribe had a clear idea of the amount of the text, so that the tablet, if made too large, was cut even before it was inscribed. For the purpose of this study it does not particularly matter in which order this was done; we will probably never be able to reconstruct the order. For now it is more important to establish that page-shaped tablets were probably cut in order to remove unnecessary clay, whereas elongated tablets may also have been cut for the purpose of rearranging the information. 
In connection to all this, I conclude with three points that remain unclear and therefore present areas for further research for the question of writing as material practice. The first point is that although Linear B had much firmer pinacological and epigraphical rules than Linear A (Tomas 2012), some uncut page-shaped tablets are too large for their text (for example, KN E 749+5532 or KN C 911), meaning that they were for some reason left uncut, even though the practice of cutting was familiar to Linear B scribes. We do not know why this is so.

Secondly, if we accept that Linear B tablets were cut to accommodate shorter texts, why are some cut tablets still too large for the text inscribed (for example, TH Av 104[+])191)? Cases like this are not plentiful, but they do recall similar cases of Linear A cut tablets from Haghia Triada, as previously discussed.

The final point may simply be a coincidence resulting from the poor state of preservation of Linear B tablets, but it is very interesting to note that in Knossos the left or the right side of many fully preserved elongated tablets has been produced by cutting (e.g. KN Fp 5, KN V 56 from other Knossian deposits, or KN Sc 103+5069+5145 and numerous examples from the RCT). Only a few fully preserved elongated tablets from Knossos have uncut edges! It is usually assumed that the Linear B flatteners formed smaller individual elongated tablets for an already targeted textual record, but this cutting evidence begs the question of whether this was really the case at Knossos. It is more likely that the flatteners would typically produce one long elongated tablet with no particular text in mind, and such a tablet was then written and cut into separate records as the information was forthcoming. Once the corpus is published, it will be interesting to see whether the Pylian elongated tablets support this suggestion and what other evidence may emerge to further clarify our understanding of these documents in relation to material practice.

\section{Notes}

${ }^{1}$ Although in the National Archaeological Museum at Athens I had the opportunity to examine some Pylian tablets that appear to be cut deliberately (I thank Dr Lena Papazoglou-Manioudaki for granting me permission to examine the tablets), an understanding of the overall practice of cutting the Pylian tablets can be achieved only once this corpus is published.

2 Such tablets are: $\mathrm{Vc}(1) 64 \oplus \mathrm{Xd} 170 \oplus \mathrm{Vc}(1)$ 7540; Vc(1) $81 \oplus \mathrm{Vc}(1)$ 199; Vc(1) $108 \oplus \mathrm{Vc}(1)$ 184; $\mathrm{Vc}(1) 125 \oplus \mathrm{Vc}(1) 312 ; \mathrm{Xd} 179 \oplus \mathrm{Xd}$ 191; Xd $216 \oplus \mathrm{Xd} 287$; Xd $123 \oplus \mathrm{Vc}(1) 108 \oplus \mathrm{Vc}(1)$ 184; Vc(1) $181 \oplus \mathrm{Xd} 7838$; Xd $7933 \oplus \mathrm{I} / 3-28$ (Driessen 1987: 156-157, 162, pls I-III).

3 These tablets are: Vd 62, Vc 64, Vd 136, Vd 137, Vd 138, Vd $7545+137$ and possibly Vc 7529.

${ }^{4}$ Vc 216 is a very interesting tablet from this point of view. It has an incomplete word since it is broken in the middle of the fourth sign. On the left edge the number one precedes the word. It has been suggested that this tablet was cut at the wrong place and that the number actually referred to the word inscribed before the preserved one (Chadwick 1968: 18).

5 Tablets: \#120 (inscribed on both sides, but with a line on only one side); four-sided bars: \#050 (a line on only one side), \#057 (lines on three sides), \#059 (two parallel lines on one side), \#061 (on all four sides), \#063 (on two sides), \#095 (two pairs of two parallel lines on one side), \#111 (still visible on one side, the rest of the document is badly damaged), \#112 (on three sides), \#113 (on three sides), \#116 (on one side); two-sided bars: \#089 (on both sides), \#092 (on one side), \#109 (on one side), and one line on the two-sided bar from Kato Syme. The numbering of the inscriptions follows the classification in Olivier and Godart 1996. For the Kato Syme document, not included in the corpus, see Lebessi et al. 1995.

${ }^{6}$ Vertical lines are present on some Hieroglyphic seals as well, where they divide syllabic signs

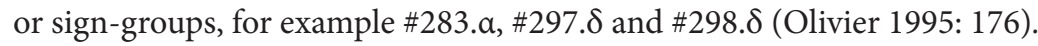




\section{References}

Andreadaki-Vlasaki, M. and Hallager, E. 2007. New and Unpublished Linear A and Linear B Inscriptions from Khania. Proceedings of the Danish Institute at Athens 5: 7-22.

Aravantinos, V. L., Godart, L. and Sacconi, A. 2002. Thèbes: Fouilles de la Cadmée III. Corpus des documents d'archives en linéaire B de Thèbes (1-433). Pisa and Rome: Pasiphae.

Aravantinos, V. L., Godart, L. and Sacconi, A. 2008. La tavoletta TH Uq 434. In Sacconi, A., del Freo, M., Godart, L. and Negri, M. (eds), Colloquium Romanum: Atti del XII Colloquio Internazionale de Micenologia. Roma, 20-25 febbraio 2006. Pisa and Rome: Pasiphae, 23-33.

Aura-Jorro, F. 1985. Diccionario Micénico, Volume 1. Madrid: Instituto de Filología.

Begg, I. D. J. 1987. Continuity in the West Wing at Knossos. In Hägg, R. and Marinatos, N. (eds), The Function of the Minoan Palaces: Proceedings of the Fourth International Symposium at the Swedish Institute in Athens, 10-16 June 1984. Stockholm: Svenska Institutet i Athen, 179-184.

Bennet, J. 1988. 'Outside in the Distance': Problems in understanding the economic geography of Mycenaean palatial territories. In Olivier, J.-P. and Palaima, T. G. (eds), Texts, Tablets and Scribes: Studies in Mycenaean epigraphy and economy offered to Emmett L. Bennett, Jr. (Minos Supplement 10). Salamanca: Ediciones universidad de Salamanca, 19-41.

Bennett, E. L. 1958. The Mycenae Tablets II (Transactions of the American Philosophical Society 48/1). Philadelphia: The American Philosophical Society.

Blegen, C. W. and Rawson, M. 1966. The Palace of Nestor at Pylos in Western Messenia, Volume 1. Princeton: Princeton University Press.

Chadwick, J. 1958. The Mycenaean Filing System. Bulletin of the Institute of Classical Studies 5(1): 1-5. DOI: http://dx.doi.org/10.1111/j.2041-5370.1958.tb00606.x

Chadwick, J. 1968. The Organization of the Mycenaean Archives. In Bartonĕk, A. (ed.), Studia Mycenaea: Proceedings of the Mycenaean Symposium, Brno, April 1966. Brno: Universita J. E. Purkyně, 11-21.

Chadwick, J., Godart, L., Killen, J. T., Olivier, J.-P., Sacconi, A. and Sakellarakis, Y. A. 1986 (I), 1990 (II), 1997 (III), 1998 (IV). Corpus of Mycenaean Inscriptions from Knossos (Incunabula Graeca 88). Cambridge and Rome: Cambridge University Press - Edizioni dell'Ateneo.

Chapouthier, F. 1930. Les écritures minoennes au palais de Mallia (Études Crétoises 2). Paris: Geuthner.

del Freo, M. 2007. Rapport 2001-2005 sur les textes en écriture hiéroglyphique crétoise, en linéaire A et en linéaire B. In Sacconi A., del Freo, M., Godart, L. and Negri, M. (eds), Colloquium Romanum: Atti del XII Colloquio Internazionale de Micenologia. Roma, 20-25 febbraio 2006. Pisa and Rome: Pasiphae, 199-222.

Driessen, J. 1987. Observations on 'Simili-joins' in the Room of the Chariot Tablets at Knossos. In Killen, T., Melena J. L. and Olivier, J.-P. (eds), Studies in Mycenaean and Classical Greek Presented to John Chadwick (Minos 20-22). Salamanca: Universidad de Salamanca, 151-162.

Driessen, J. 1988. The Scribes of 'The Room of the Chariot Tablet'. In Olivier, J.-P. and Palaima, T. G. (eds), Texts, Tablets and Scribes: Studies in Mycenaean epigraphy and economy offered to Emmett L. Bennett, Jr. (Minos Supplement 10). Salamanca: Universidad de Salamanca, 123-165.

Driessen, J. 1990. An Early Destruction in the Mycenaean Palace at Knossos: A new interpretation of the excavation field-notes of the South-East area of the west wing (Acta Archaeologica Lovaniensia - Monographiae 2). Leuven: Katholieke Universiteit Leuven.

Driessen, J. 1992. Collector's Items: Observations sur l'élite mycénienne de Cnossos. In Olivier, J.-P. (ed.), Mykenaïka. Actes du IXe Colloque international sur les textes mycéniens et égéens organisé par le Centre de l'Antiquité Grecque et Romaine de la Fondation Hellénique des Recherches 
Scientifiques et l'École française d'Athènes, Athènes, 2-6 Octobre 1990 (Supplement to Bulletin de Correspondance Hellénique, no. 25). Paris: de Boccard, 197-214.

Driessen, J. 1998-1999. Kretes and Iawones: Some observations on the identity of Late Bronze Age Knossians. In Bennet, J. and Driessen, J. (eds), A-na-qo-ta. Studies Presented to J. T. Killen (Minos 33-34). Salamanca: Universidad de Salamanca, 83-105.

Driessen, J. 1999. The Northern Entrance Passage at Knossos: Some preliminary observations on its potential role as 'Central Archive'. In Deger-Jalkotzy, S., Hiller, S. and Panagl, O. (eds), Floreant Studia Mycenaea: Akten des X. Internationalen Mykenologischen Colloquiums in Salzburg vom 1.-5. Mai 1995. Vienna: Österreichischen Akademie der Wissenschaften, 205-226.

Driessen, J. 2000. The Scribes of the Room of the Chariot Tablets at Knossos: Interdisciplinary approach to the study of a Linear B deposit (Minos Supplement 15). Salamanca: Universidad de Salamanca.

Driessen, J. 2008. Chronology of the Linear B Texts. In Duhoux, Y. and Morpurgo Davies, A. (eds), A Companion to Linear B: Mycenaean Greek texts and their world. Louvain-la-Neuve: Peeters, 69-79.

Driessen, J. and Schoep, I. 1999. The Stylus and the Sword: The role of scribes and warriors in the conquest of Crete. In Laffineur, R. (ed.), Polemos: Le Contexte Guerrier en Égée à l'Âge du Bronze. Actes de la $7^{e}$ Recontre égéene internationale, Université de Liège, 14-17 Avril 1998 (Aegaeum 19). Liège and Austin: Université de Liège and University of Texas at Austin, 389-401.

Duhoux, Y. 1978. Une analyse linguistique du linéaire A. In Duhoux, Y. (ed.), Études Minoennes, I. Le linéaire A. Louvain: Institut de Linguistique de Louvain, 65-129.

Duhoux, Y. 1999. La séparation des mots en linéaire B. In Deger-Jalkotzy, S., Hiller, S. and Panagl, O. (eds), Floreant Studia Mycenaea, Akten des X. Internationalen Mykenologischen Colloquiums in Salzburg vom 1.-5. Mai 1995. Vienna: Österreichische Akademie der Wissenschaften, 227-236.

Evans, A. 1935. The Palace of Minos at Knossos, Volume 4. London: Macmillan.

Firth, R. 2012. Re-visiting the Tablet-makers of Knossos. In Kyriakidis, E. (ed.), Proceedings of the International Colloquium "The Inner Workings of Mycenaean Bureaucracy", University of Kent, Canterbury, 19-21 September 2008 (Pasiphae, Rivista di filologia e antichità egee V). Rome and Pisa: Fabrizio Serra Editore, 81-94.

Godart, L. 1988. Autour des textes en linéaire B de Tirynthe: Ausgrabungen in Tiryns 1982/83. Archäologischer Anzeiger 1988: 245-251.

Godart, L. 1999. Lécriture d'Arkhanès: hiéroglyphique ou linéaire A? In Betancourt, P. P., Karageorghis, V., Laffineur, R. and Niemeier, W.-D. (eds), Meletemata: Studies in Aegean archaeology presented to Malcolm H. Wiener as he enters his $65^{\text {th }}$ year (Aegaeum 20). Liège and Austin: Université de Liège and University of Texas at Austin, 299-302.

Godart, L. and Olivier, J.-P. 1976 (I), 1979 (II), 1976 (III), 1982 (IV), 1985 (V). Recueil des inscriptions en linéaire A. Paris: École française d’Athènes.

Godart, L. and Tzedakis, Y. 1992. Témoignages archéologiques et épigraphiques en Crète occidentale du Néolithique au Minoen récent III B (Incunabula Graeca 93). Rome: Istituto per gli Studi Micenei ed Egeo-Anatolici.

Grumach, E. and Sakellarakis, Y. 1966. Die neuen Hieroglyphensiegel vom Phourni (Archanes) I. Kadmos 5(2): 109-114. DOI: http://dx.doi.org/10.1515/kadm.1966.5.2.109

Halbherr, F., Stefani, E. and Banti, L. 1977. Haghia Triada nel periodo tardo palaziale. Annuario della Scuola Archeologica di Atene 55: 9-296.

Hallager, E. and Vlasaki, M. 1997. New Linear B Tablets from Khania. In Driessen, J. and Farnoux, A. (eds), La Crète mycénienne (Supplement to Bulletin de Correspondance Hellénique, no. 30). Athens: Centre national de la Recherche scientifique, 169-174. 
Killen, J. T. 1981. Mycenaean Possessive Adjectives in -e-jo. Transactions of the Philological Society 1981: 66-99.

Lebessi, A., Muhly, P. and Olivier, J.-P. 1995. An Inscription in the Hieroglyphic Script from the Syme Sanctuary, Crete (SY Hf 01). Kadmos 34(1): 63-77. DOI: http://dx.doi.org/10.1515/ kadm.1995.34.1.63

Melena, J. and Olivier, J.-P. 1991. Tithemy: The tablets and nodules in Linear B from Tiryns, Thebes and Mycenae (Minos Supplement 12). Salamanca: Universidad de Salamanca.

Olivier, J.-P. 1984. Administrations at Knossos and Pylos: What differences. In Shelmerdine, C. W. and Palaima, T. G., Pylos Comes Alive: Industry + administration in a Mycenaean palace. New York: Fordham University, 11-18.

Olivier, J.-P. 1987. Structure des archives palatiales en linéaire A et en linéaire B. In Lévy, E. (ed.), Le système palatial en Orient, en Grèce et à Rome. Actes du Colloque de Strasbourg 19-22 juin 1985. Leiden: Université des sciences humaines de Strasbourg, 227-235.

Olivier, J.-P. 1994. L'économie des royaumes mycéniens d'après les tablettes en linéaire B. Les Dossiers d'Archéologie 195: 50-65.

Oliver, J.-P. 1994-1995. Un simili-raccord dans les barres en hiéroglyphique de Knossos (CHIC \#057 $\oplus \# 058$ ). Minos 29-30: 257-269.

Olivier, J.-P. 1995. Les sceaux avec des signes hiéroglyphiques: Que lire? Une question de bon sens. In Müller, W. (ed.), Sceaux minoens and mycéniens, IVe symposium international 10-12 Septembre 1992, Clermont-Ferrand (Corpus der Minoischen und Mykenischen Siegel, Beiheft 5). Mainz: Akademie der Wissenschaften und der Literatur, 169-181.

Olivier, J.-P. and Godart, L. 1996. Corpus Hieroglyphicarum Inscriptionum Cretae (Études Crétoises 31). Paris: École française d'Athènes and École française de Rome.

Palaima, T. G. 1983. Evidence for the Influence of the Knossian Graphic Tradition at Pylos. Concilium Eirene 16: 80-84.

Palaima, T. G. 1985. Appendix. In Åström, P. and Sjöquist, K.-E. Pylos: Palmprints and palmleaves (Studies in Mediterranean Archaeology, Pocket Book, no. 31). Göteburg: Paul Åströms Förlag, 99-107.

Palaima, T. G. 1988. The Scribes of Pylos (Incunabula Graeca 87). Rome: Edizioni Dell'Ateneo.

Palaima, T. G. 1996. 'Contiguities' in the Linear B Tablets from Pylos. In de Miro, E., Godart, L. and Sacconi, A. (eds), Atti e Memorie del Secondo Congresso Internazionale di Micenologia (Incunabula Graeca 98). Rome: Istituto per gli studi micenei, 379-396.

Palaima, T. G. and Wright, J. C. 1985. Ins and Outs of the Archives Rooms at Pylos: Form and function in a Mycenaean Palace. American Journal of Archaeology 89: 251-262. DOI: http:// dx.doi.org/10.2307/504328

Pluta, K. M. 1996-1997. A Reconstruction of the Archives Complex at Pylos: A preliminary report. Minos 31-32: 231-250.

Pugliese Carratelli, G. 1958. Nuove epigrafi minoiche di Festo. Annuario della Scuola Archeologica di Atene 35-36: 363-388.

Sacconi, A. 1974. Corpus delle iscrizioni vascolari in lineare B (Incunabula Graeca 58). Rome: Edizioni dell'Ateneo.

Sakellarakis, Y. and Sapouna-Sakellaraki, E. 1997. Archanes: Minoan Crete in a new light. Athens: Ammos Publications.

Schoep, I. 1998-1999. Minoan Administration at Haghia Triada: A multi-disciplinary comparison of the Linear A tablets from the Villa and the Casa del Lebete. In Bennet, J. and Driessen, J. (eds), A-na-qo-ta: Studies presented to J. T. Killen (Minos 33-34). Salamanca: Universidad de Salamanca, 273-294.

Schoep, I. 2001. Some Notes on the 'Hieroglyphic' Deposit from Knossos. Studi Micenei ed EgeoAnatolici 43(1): 143-158. 
Schoep, I. 2002. The Administration of Neopalatial Crete: A critical assessment of the Linear A tablets and their role in the administrative process (Minos Supplement 17). Salamanca: Universidad de Salamanca.

Schoep, I. 2007. The Inscribed Document. In Macdonald, C. F. and Knappett, C. (eds), Knossos: Protopalatial deposits in early magazine A and the south-west houses (British School of Athens Supplementary Volume 41). London: British School of Archaeology at Athens, 131-134.

Shelmerdine, C. W. and Bennet, J. 2008. Mycenaean States: Economy and administration. In Shelmerdine, C. W. (ed.), The Cambridge Companion to the Aegean Bronze Age. Cambridge: Cambridge University Press, 289-309. DOI: http://dx.doi.org/10.1017/CCOL9780521814447.013

Shelton, K. 2002-2003. A New Linear B Tablet from Petsas House, Mycenae. Minos 37-38: 387-396. Sjöquist, K.-E. and Åström, P. 1991. Knossos: Keepers and kneaders (Studies in Mediterranean Archaeology, Pocket book, no. 82). Gothenburg: Paul Åströms Förlag.

Tomas, H. 2003. Understanding the Transition between Linear A and Linear B Scripts. Unpublished D.Phil. dissertation, University of Oxford.

Tomas, H. 2010. Cretan Hieroglyphic and Linear A. In Cline, E. H. (ed.), The Oxford Handbook of the Bronze Age Aegean. Oxford: Oxford University Press, 340-355.

Tomas, H. 2011. Linear A tablet $\neq$ Linear B tablet. In Andreadaki-Vlazaki, M. and Papadopoulou, E. (eds), Pepragmena tou I' Diethnous Kritologikou Synedriou / Proceedings of the $10^{\text {th }}$ Cretological Conference, Hania, 1-8 October 2006, Volume A1. Chania: Filologikos Syllogos "O Hrysostomos", 331-343.

Tomas, H. 2012. Linear A Scribes and Their Writing Styles. In Kyriakidis, E. (ed.), Proceedings of the International Colloquium "The Inner Workings of Mycenaean Bureaucracy", University of Kent, Canterbury, 19-21 September 2008 (Pasiphae, Rivista di filologia e antichità egee V). Rome and Pisa: Fabrizio Serra Editore, 35-58.

Warren, P. and Hankey, V. 1989. Aegean Bronze Age Chronology. Bristol: Bristol Classical Press.

Younger, J. G. and Rehak, P. 2008. Minoan Culture: Religion, burial customs, and administration. In Shelmerdine, C. W. (ed.), The Cambridge Companion to the Aegean Bronze Age. Cambridge: Cambridge University Press, 165-185. http://dx.doi.org/10.1017/CCOL9780521814447.008 